\title{
HUBUNGAN ANTARA UMUR DAN INTENSITAS CAHAYA LAS DENGAN KELELAHAN MATA PADA JURU LAS PT. X DI KABUPATEN GRESIK
}

\author{
Dedy Setiawan \\ PT. Setyanan Mahakarya Prima \\ Jl. Gayungsari I no. 36, Surabaya 60235 Indonesia \\ Email: p_dedy.setiawan_q@yahoo.co.id
}

\begin{abstract}
Welding occurs much hazard especially toward welders eyestrain. The Objective of study was to analyzed relation between age and eyestrain and also weld luminous intensity and eyestrain at welders of PT. X in District of Gresik. Research was carried out by cross sectional and observational study. Subjects were 20 welders of PT. X in District of Gresik. Data collecting was carried out by interview, measurement instrument, and examination. The independent variables were age and weld luminous intensity, and the dependent variable was eyestrain. Spearman Test was used to correlate between age and eyestrain. Pearson Product Moment Test was used to correlate between weld luminous intensity and eyestrain. According to the results, there was significant correlation between age and eyestrain $(p=0,007)$. There are more eyestrains will be occurred in older age. Result also showed that there was significant correlation between weld luminous intensity and eyestrain $(p=0,023)$. High exposure of weld luminous intensity will occurs contrast so that eyes needs much effort to adapt it. Light of weld contain UV light, visible light, and infrared radiation. In conclusion, there was significant correlation between age and eyestrain. And also, there was significant correlation between weld luminous intensity and eyestrain. Welders must use face shield depend on types of welding and company should held eyes examination to welders routinely.
\end{abstract}

Keywords: age, weld luminous intensity, eyestrain

\begin{abstract}
ABSTRAK
Pengelasan menimbulkan banyak risiko bahaya khususnya terhadap kelelahan mata juru las. Tujuan penelitian ini adalah untuk menganalisis hubungan antara umur dan intensitas cahaya las dengan kelelahan mata pada juru las PT. X di Kabupaten Gresik. Penelitian dilakukan dengan rancangan cross sectional dan observasional. Subjek adalah 20 juru las PT. $\mathrm{X}$ di Kabupaten Gresik. Pengambilan data dilakukan dengan metode wawancara, penggunaan alat ukur, dan pemeriksaan subjek. Variabel bebas penelitian adalah umur dan intensitas cahaya las, serta variabel terikat penelitian adalah kelelahan mata. Hubungan antara umur dengan kelelahan mata menggunakan uji Spearman. Hubungan antara intensitas cahaya las dengan kelelahan mata menggunakan uji Pearson Product Moment. Berdasarkan hasilnya, terdapat hubungan yang bermakna antara umur dengan kelelahan mata $(\mathrm{p}=0,007)$. Semakin banyak kelelahan mata muncul pada usia yang lebih tua. Hasil uji juga menunjukkan bahwa terdapat hubungan antara intensitas cahaya las dengan kelelahan mata $(\mathrm{p}=0,023)$. Paparan intensitas cahaya las yang tinggi akan menghasilkan kontras cahaya sehingga mata membutuhkan usaha yang lebih kuat untuk beradaptasi. Cahaya las mengandung radiasi sinar UV, cahaya tampak, dan inframera. Kesimpulan yang didapat adalah terdapat hubungan yang bermakna antara umur dengan kelelahan mata serta terdapat hubungan antara intensitas cahaya las dengan kelelahan mata. Juru las diharuskan memakai face shield yang sesuai dengan jenis pengelasannya dan perusahaan harus melakukan pemeriksaan mata secara rutin kepada juru las.
\end{abstract}

Kata kunci: umur, intensitas cahaya las, kelelahan mata

\section{PENDAHULUAN}

Baja memiliki peran yang penting untuk pembangunan infrastuktur suatu negara. Konsumsi baja merupakan indikator pembangunan bagi suatu daerah karena baja merupakan komponen yang penting sebagai bahan pembuatan peralatan industri, sarana dan prasarana transportasi darat, udara, dan laut serta konstruksi bangunan. Penurunan kebutuhan baja di suatu daerah menunjukkan adanya perlambatan pembangunan di daerah tersebut.
Agar baja dapat digunakan pada masing-masing peruntukannya, baja perlu diolah dan dibentuk dari bijih besi hingga menjadi logam baja. Baja mulai direkayasa sesuai bentuk yang dibutuhkan setelah menjadi logam baja. Proses pengelasan merupakan penyatuan plat atau logam melalui proses penyambungan akibat pemberian panas dengan atau tanpa tekanan (Fitriadi, 2008).

Pengelasan memerlukan keahlian khusus yang diakui dengan sertifikasi juru las. Juru las yang 
telah diakui melalui pelatihan dan sertifikasi akan menghasilkan kualitas las yang baik. Tidak hanya hasil yang baik tetapi juru las yang tersertifikasi telah mendapatkan pendidikan tentang risiko bahaya dan pengendalian yang dapat dilakukan untuk mengurangi dampak yang terjadi saat melakukan pengelasan.

Contoh metode pengelasan dapat berupa las busur dengan pelindung gas lembam (inert gas shielded metal arc welding), las busur dengan elektroda karbon atau grafit (carbon arc welding), las gesek (friction welding), las ultrasonik (ultrasonic welding), las sinar laser (laser welding), dan lain-lainnya. Berbagai proses di industri yang merujuk pada istilah pengelasan (welding) yaitu pembrasingan (brazing), penyolderan (soldering), las busur listrik (electric arc welding), las karbid (oxyacetylene welding), dan pemotongan (cutting) (Siswanto, 1994).

Pada saat mengelas, banyak sekali sumber bahaya yang dapat membahayakan juru las. Bahaya tersebut dapat berupa paparan panas, tersengat listrik, ergonomi kerja, kabel las yang berantakan dan paparan intensitas cahaya las yang tinggi. Hal lain yang dapat memperburuk risiko bahaya juga dapat berasal dari faktor individu pekerja sendiri.

Kelelahan merupakan reaksi fungsionil dari cortex cerebri yang dipengaruhi oleh sistem penghambat dan sistem penggerak. Munculnya kelelahan dapat mengurangi kinerja dan ketahanan tubuh terhadap pekerjaannya. Oleh karena itu terjadinya kelelahan pada tenaga kerja perlu diawasi oleh pihak yang terkait (Suma'mur, 2009).

Menurut Grandjean (1988), salah satu jenis kelelahan adalah kelelahan mata. Kelelahan mata terjadi akibat penggunaan fungsi penglihatan secara intensif sehingga memicu penurunan ketahanan penglihatan. Kelelahan mata dapat terjadi pada juru las karena munculnya bunga api dari las menciptakan intensitas cahaya yang tinggi pada medan pandang juru las.

Pada pekerjaan juru las, cahaya yang dipancarkan dari pengelasan dapat memberikan efek kelelahan pada mata. Cahaya dari las dapat mengakibatkan kerusakan pada mata. Kondisi sakit dari kerusakan mata ini akan terasa secara tidak langsung tetapi akan muncul satu hingga dua hari dan kemudian akan menghilang (Andryansyah, 2000).

Pada penelitian yang dilakukan oleh Angelina dan Oginawati (2010), Intensitas cahaya yang muncul dari pengelasan berkisar dari 500 lux hingga 18000 lux. Intensitas cahaya las dapat beragam bergantung pada jenis mesin las, jenis pekerjaan, jenis serta ketebalan bahan yang dilas. Intensitas cahaya las yang tinggi dapat memicu terjadinya kontras cahaya. Sinar yang dihasilkan dari pengelasan mengandung radiasi sinar ultraviolet (200-400 nm), radiasi cahaya tampak (400-700 nm), dan radiasi inframerah $(700-1400 \mathrm{~nm})$.

Kontras merupakan kondisi di mana terdapat perbedaan tingkat terang antara objek pandang dengan lingkungan sekitarnya. Pengelasan akan menghasilkan kontras cahaya yang tajam sehingga kepekaan mata terhadap kontras akan meningkat juga. Kepekaan terhadap kontras pada area permukaan kecil juga lebih besar daripada pada area permukaan yang besar (Santoso, 2004).

Mata melakukan kemampuan beradaptasi pada saat terjadi perubahan kondisi dari gelap ke terang maupun sebaliknya. Kemampuan adaptasi gelap maupun terang tersebut tergantung pada kondisi retina seseorang. Semakin cepat adanya perubahan kondisi dari gelap ke terang maupun sebaliknya, maka lama waktu proses adaptasi akan semakin memanjang. Terdapat tiga jenis cahaya silau yaitu sinar relatif, sinar mutlak, dan sinar adaptif. Sinar relatif terjadi ketika kontras cahaya sangat tinggi pada medan pandang. Sinar mutlak terjadi ketika cahaya sangat cerah sehingga adaptasi oleh mata menjadi sulit dilakukan. Sinar adaptif terjadi apabila adaptasi terjadi pada tingkat terang tertentu namun masih belum tercapai (Sedarmayanti, 2011).

Kesilauan sendiri dibedakan menjadi dua jenis yaitu discomfort glare dan disability glare. Discomfort glare menimbulkan rasa ketidaknyamanan pada mata (visual discomfort). Visual discomfort akan semakin terasa apabila paparan cahaya tampak yang terang terjadi dalam jangka waktu yang cukup lama. Pada disability glare, seseorang akan mengalami kebutaan sementara akibat paparan cahaya tampak yang sangat terang atau biasa disebut dengan flash blindness. Flash blindness terjadi karena pigmen penglihatan menjadi berwarna putih setelah paparan cahaya yang terang. Pigmen ini akan memutih sehingga membentuk scotoma atau daerah kebutaan sementara pada medan pandang orang tersebut (Siswanto, 1994).

Menurut Amstrong (1992) dalam Tarwaka dkk (2004), pencahayaan yang berlebihan dapat menyebabkan gangguan visibilitas dan eyestrain atau kelelahan mata. Pencahayaan yang berlebihan menghasilkan intensitas cahaya yang tinggi sehingga dapat menyebabkan kelelahan mata. Intensitas 
cahaya las yang tinggi menyebabkan kesilauan yang mengganggu adaptasi retina sehingga menyebabkan rasa ketidaknyamanan pada mata.

Faktor lain yang memiliki kaitan dengan kelelahan mata selain intensitas cahaya yang tinggi adalah umur. Dengan bertambahnya umur seseorang, akan terjadi penurunan kemampuan fungsi organ tubuh termasuk organ mata. Selama mengelas, juru las di tuntut untuk memandang objek dengan intensitas cahaya yang terang dan memfokuskan pada ukuran objek yang kecil. Kondisi tersebut menuntut juru las untuk memiliki kondisi mata yang prima untuk menjaga produktifitasnya.

Manusia memiliki siklus hidup dari proses pembuahan hingga mencapai usia tua. Selama perjalanannya, manusia mengalami perubahan dan perkembangan baik secara fisik maupun mentalnya. Perubahan dan perkembangan tersebut menyebabkan adanya perbedaan kemampuan manusia dalam melakukan kegiatan sehari-harinya.

Perubahan yang terjadi pada manusia bersifat meningkat hingga pada umur tertentu dan kemudian mulai menurun setelah mencapai puncaknya. Kemampuan fisik manusia sangat lemah pada usia muda dan menjadi kuat pada puncak produktivitasnya. Kemampuan fisik manusia semakin lemah akibat degenerasi fungsi organ setelah mengalami puncak produktivitasnya.

Pada tenaga kerja sebagai juru las, tidak terdapat tenaga kerja yang di bawah umur. Hal ini mengingat aturan perundang-undangan di Indonesia yang melarang mempekerjakan anak di bawah 18 tahun. Oleh karena itu kemampuan fisik yang dapat ditunjukkan oleh tenaga kerja terkait perbedaan umurnya adalah penurunan kemampuan fisik pada tenaga kerja yang lebih tua.

Penurunan fungsi organ tubuh juga terjadi pada organ penglihatan. Menurut Fowler (2003), pada usia diatas 35 tahun seseorang akan mulai merasakan adanya penurunan ketajaman penglihatan. Penurunan ketajaman penglihatan menunjukkan terjadinya penurunan fungsi organ mata manusia pada usia tersebut. Ketika mengelas, dampak dari penurunan fungsi mata akibat umur memiliki kaitan pula dengan kelelahan mata karena terjadi penurunan ketahanan mata akibat tekanan/stress dari faktor pekerjaan yang diterima oleh mata.

Tujuan dari penelitian ini adalah untuk menganalisis hubungan antara umur dan intensitas cahaya las dengan kelelahan mata pada juru las PT. X di Kabupaten Gresik.

\section{METODE}

Penelitian ini adalah penelitian observasional karena penelitian ini tidak memberikan perlakuan kepada sasaran penelitian dan hanya mengamati gambaran yang ada di lapangan. Penelitian juga termasuk dalam penelitian cross sectional karena pengamatan faktor paparan dan kejadian kasus dilakukan pada waktu yang bersamaan dan waktu itu juga. Penelitian dilakukan untuk melihat apakah terdapat hubungan antara faktor-faktor yang diteliti dengan menggunakan uji korelasi.

Penelitian dilakukan di PT. X yang merupakan salah satu perusahaan yang bergerak di bidang fabrikasi baja di Gresik. Penelitian dilakukan pada Bulan Juni 2015. Populasi penelitian adalah semua juru las yang bekerja di PT. X yang berlokasi di Kabupaten Gresik sebanyak 20 orang. Sampel penelitian adalah total populasi yaitu semua juru las yang bekerja di PT. X yang berlokasi di Kabupaten Gresik yang berjumlah 20 orang.

Variabel bebas penelitian adalah umur dan intensitas cahaya, sedangkan variabel terikat penelitian adalah kelelahan mata. Definisi umur adalah lama tahun dari tanggal lahir responden hingga tanggal pengambilan data. Definisi intensitas cahaya las adalah flux cahaya yang berasal dari cahaya las yang jatuh pada $1 \mathrm{~m}^{2}$ pada posisi kerja responden. Definisi kelelahan mata adalah ketegangan pada mata akibat dari penggunaan indera penglihatan dalam jangka waktu yang lama dan umumnya disertai dengan kondisi mata yang tidak nyaman.

Variabel umur didapatkan dengan metode kuesioner. Variabel intensitas cahaya las didapatkan dengan pengukuran menggunakan luxmeter. Variabel kelelahan mata didapatkan dengan pemeriksaan Photostress Recovery Test. Variabel umur berskala data ordinal dan diklasifikasikan menjadi empat kelompok umur, yaitu di bawah 25 tahun, 26-35 tahun, 36-45 tahun, dan diatas 46 tahun. Variabel intensitas cahaya las dan kelelahan mata berskala data rasio.

Pengukuran intensitas cahaya las dilakukan dengan metode mengukur intensitas cahaya lokal di tempat juru las bekerja. Pengukuran dilakukan selama 5 menit dalam posisi juru las sedang bekerja dengan jarak 1 meter dari titik api las. Nilai yang diambil merupakan nilai intensitas cahaya las yang tertinggi muncul di pekerjaan tersebut.

Pengukuran kelelahan mata dilakukan dengan pemeriksaan Photostress Recovery Test. 
Pemeriksaan photostress recovery test dilakukan untuk mengevaluasi fungsi retina dengan mengukur waktu yang dibutuhkan untuk pemulihan dari cahaya setelah terjadi bleaching. Cara pemeriksaan photostress recovery test yang umum adalah dengan acuity chart (Ito, dkk. 1997).

Pemeriksaan Photostress Recovery Test dilakukan oleh dokter. Pemeriksaan kelelahan mata dilakukan seketika setelah juru las melakukan pengelasan. Sebelum masuk pada pemeriksaan kelelahan, akan dilakukan pemeriksaan visus mata kanan dan kiri untuk menentukan tajam penglihatan subjek.

Pemeriksaan kelelahan mata diawali dengan menempatkan subjek pada jarak enam meter dari Snellen Chart. Salah satu mata disinari menggunakan penlight atau lampu senter dengan jarak $2-3 \mathrm{~cm}$ dari mata selama 10 detik. Sesaat setelah penyinaran dimatikan, subjek diminta membaca huruf pada Snellen Chart hingga minimal dapat membaca tiga huruf pada satu tingkat lebih tinggi dari tajam penglihatan terbaiknya. Penyinaran dan pembacaan huruf diulangi pada sisi mata yang lain (Suharyanto dan Safari, 2010).

Nilai kelelahan mata kanan dan kiri didapatkan dan di rata-rata untuk menentukan nilai kelelahan mata subjek. Pada penelitian yang dilakukan oleh Marsida (1999), didapatkan bahwa orang dengan kondisi mata yang normal tanpa beban kerja yang diperiksa menggunakan Photostress Recovery Test didapatkan hasil rata-rata untuk mata kanan sebesar 13,5 detik dan mata kiri sebesar 15,75 detik sehingga didapatkan hasil rata-rata untuk mata normal adalah 14,625 detik. Nilai tersebut dijadikan sebagai cut off point dari kelelahan mata.

Uji hubungan antara umur dengan kelelahan mata dilakukan dengan uji Spearman dengan CI $95 \%$ dan $=0,05$. Pengujian dilakukan dengan uji Spearman karena skala data umur adalah ordinal dan skala data kelelahan mata adalah rasio. Apabila hasil uji statistik menunjukkan nilai p-value $\leq$ alpha $(0,05)$ maka $\mathrm{H}_{0}$ ditolak dan artinya terdapat hubungan antara umur dengan kelelahan mata. Apabila nilai p-value $>$ alpha $(0,05)$ maka $\mathrm{H}_{0}$ diterima dan artinya tidak terdapat hubungan antara umur dengan kelelahan mata.

Uji hubungan antara intensitas cahaya las dengan kelelahan mata dilakukan dengan uji Pearson Product Moment atau Spearman tergantung pada normal atau tidaknya distribusi data. Apabila uji normalitas menunjukkan bahwa data intensitas cahaya las dan kelelahan mata berdistribusi normal, maka uji yang digunakan adalah uji Pearson Product Moment. Apabila salah satu atau kedua data intensitas cahaya las dan kelelahan mata tidak berdistribusi normal, maka uji yang digunakan adalah uji Spearman.

Uji hubungan antara intensitas cahaya las dan kelelahan mata dilakukan dengan CI 95\% dan $=0,05$ setelah penentuan normal atau tidaknya distribusi data. Apabila hasil uji statistik menunjukkan nilai p-value $\leq$ alpha $(0,05)$ maka $\mathrm{H}_{0}$ ditolak dan artinya terdapat hubungan antara intensitas cahaya las dengan kelelahan mata. Apabila nilai p-value $>$ alpha $(0,05)$ maka $\mathrm{H}_{0}$ diterima dan artinya tidak terdapat hubungan antara intensitas cahaya las dengan kelelahan mata.

\section{HASIL}

\section{Umur}

Berdasarkan hasil yang didapat, diketahui bahwa 3 orang atau $15 \%$ responden termasuk kelompok umur di bawah 25 tahun, 11 orang atau $55 \%$ responden termasuk kelompok umur 26 hingga 35 tahun, 3 orang atau $15 \%$ responden termasuk kelompok umur 36 hingga 45 tahun, dan 3 orang atau $15 \%$ responden termasuk kelompok umur diatas 46 tahun. Hasil tersebut menunjukkan bahwa sebagian besar responden memiliki kelompok umur 26 hingga 35 tahun yaitu sebanyak 11 orang atau $55 \%$.

\section{Intensitas Cahaya Las}

Berdasarkan hasil yang didapat, diketahui bahwa nilai intensitas cahaya las memiliki hasil yang berbeda-beda dengan nilai terendah intensitas cahaya las adalah 758 lux pada responden ke-20 dan nilai tertinggi adalah 2025 lux pada responden ke 16. Range nilai intensitas cahaya sebesar 1267 lux. Rata-rata nilai intensitas cahaya las tersebut adalah 1505 lux.

\section{Kelelahan Mata}

Berdasarkan hasil yang didapat, diketahui bahwa 17 orang atau $85 \%$ responden mengalami kelelahan mata.

Tiga orang atau $15 \%$ responden tidak mengalami kelelahan mata. Hasil tersebut menunjukkan bahwa sebagian besar responden mengalami kelelahan mata. 
Tabel 1. Distribusi Silang antara Umur dengan Kelelahan Mata

\begin{tabular}{|c|c|c|c|c|c|c|}
\hline \multirow{3}{*}{ Umur } & \multicolumn{4}{|c|}{ Kelelahan Mata } & \multirow{2}{*}{\multicolumn{2}{|c|}{ Jumlah }} \\
\hline & \multicolumn{2}{|c|}{ Tidak Mengalami Kelelahan mata } & \multicolumn{2}{|c|}{ Mengalami Kelelahan Mata } & & \\
\hline & $\mathbf{n}$ & $\%$ & $\mathbf{N}$ & $\%$ & $\mathbf{n}$ & $\%$ \\
\hline$\leq 25$ tahun & 1 & 33,3 & 2 & 11,8 & 3 & 15 \\
\hline 26-35 tahun & 2 & 66,7 & 9 & 52,9 & 11 & 55 \\
\hline $36-45$ tahun & 0 & 0 & 3 & 17,6 & 3 & 15 \\
\hline$\geq 46$ tahun & 0 & 0 & 3 & 17,6 & 3 & 15 \\
\hline Total & 3 & 100 & 17 & 100 & 20 & 100 \\
\hline
\end{tabular}

\section{Hubungan antara Umur dengan Kelelahan Mata}

Berdasarkan Tabel 1, diketahui distribusi antara kelompok umur responden dengan kelelahan mata yang terjadi pada responden. Tiga responden tidak mengalami kelelahan mata diketahui berasal dari kelompok umur di bawah 25 tahun sejumlah 1 orang atau 33,3\% dan kelompok umur 26 hingga 35 tahun sejumlah 2 orang $66,6 \%$. Tujuh belas responden yang mengalami kelelahan mata diketahui berasal dari kelompok umur di bawah 25 tahun sejumlah 2 orang atau $11,8 \%$, kelompok umur 26 hingga 35 tahun sejumlah 9 orang atau 52,9\%, kelompok umur 36 hingga 45 tahun sejumlah 3 orang atau 17,6\%, dan kelompok umur diatas 46 tahun sejumlah 3 orang atau $17,6 \%$.

Uji hubungan antara umur dengan kelelahan mata dianalisis menggunakan uji Spearman dengan CI $95 \%$ dan $=0,05$. Melalui uji statistik diperoleh nilai $p=0,007 \alpha=0,05(p<\alpha)$, maka Ho ditolak sehingga dapat disimpulkan bahwa terdapat hubungan antara umur dengan kelelahan mata pada juru las PT. X di Kabupaten Gresik.

\section{Hubungan antara Intensitas Cahaya Las dengan Kelelahan Mata}

Berdasarkan Tabel 2, diketahui distribusi antara kelompok intensitas cahaya dengan kelelahan mata

Tabel 2. Distribusi Silang antara Intensitas Cahaya Las dengan Kelelahan Mata

\begin{tabular}{cccc}
\hline Responden & Intensitas Cahaya Las (Lux) & Nilai Kelelahan Mata (Detik) & Keterangan \\
\hline 1 & 1028 & 7.5 & Tidak Kelelahan Mata \\
2 & 1298 & 15.5 & Kelelahan Mata \\
3 & 1599 & 28 & Kelelahan Mata \\
4 & 1290 & 20.5 & Kelelahan Mata \\
5 & 1794 & 26 & Kelelahan Mata \\
6 & 1957 & 27.5 & Kelelahan Mata \\
7 & 1523 & 11.5 & Tidak Kelelahan Mata \\
8 & 1489 & 18.5 & Kelelahan Mata \\
9 & 1534 & 33 & Kelelahan Mata \\
10 & 1682 & 12.5 & Tidak Kelelahan Mata \\
11 & 1741 & 26 & Kelelahan Mata \\
12 & 865 & 24 & Kelelahan Mata \\
13 & 1115 & 19.5 & Kelelahan Mata \\
14 & 1422 & 21 & Kelelahan Mata \\
15 & 1681 & 20.5 & Kelelahan Mata \\
16 & 2025 & 28 & Kelelahan Mata \\
17 & 1878 & 31.5 & Kelelahan Mata \\
18 & 1687 & 16.5 & Kelelahan Mata \\
19 & 1734 & 29 & Kelelahan Mata \\
20 & 758 & 15.5 & Kelelahan Mata \\
\hline Rata-rata & 1505 & 10,75 & \\
\hline
\end{tabular}


yang terjadi pada responden. Nilai intensitas cahaya las memiliki hasil yang berbeda pada setiap tempat dengan nilai terendah 758 lux dan nilai tertinggi 2025 lux dengan rata-rata nilai intensitas cahaya las 1505 lux. Hasil kelelahan mata menunjukkan bahwa nilai terpendek adalah 7,5 detik dan nilai terlama adalah 33 detik dengan rata-rata nilai kelelahan mata 10,75 detik. Hasil kelelahan mata dan cut off point kelelahan mata sebesar 14,625 detik, maka dapat disimpulkan bahwa terdapat 17 responden mengalami kelelahan mata dan 3 responden tidak mengalami kelelahan mata.

Uji hubungan antara intensitas cahaya las dengan kelelahan mata diawali dengan uji normalitas intensitas cahaya yang diperoleh nilai $\mathrm{p}=0,31$ $\alpha=0,05(\mathrm{p}>\alpha)$ dan uji normalitas kelelahan mata yang diperoleh nilai $\mathrm{p}=0,771 \alpha=0,05(\mathrm{p}>\alpha)$. Uji normalitas pada data intensitas cahaya las dan kelelahan mata menghasilkan kesimpulan bahwa $\mathrm{H}_{0}$ diterima sehingga distribusi kedua data tersebut normal dan memenuhi syarat untuk uji Pearson Product Moment. Uji hubungan antara intensitas cahaya las dengan kelelahan mata dianalisis menggunakan uji Pearson Product Moment dengan CI $95 \%$ dan $=0,05$. Melalui uji statistik diperoleh nilai $\mathrm{p}=0,023 \alpha=0,05(\mathrm{p}<\alpha)$, maka Ho ditolak sehingga dapat disimpulkan bahwa terdapat hubungan antara intensitas cahaya las dengan kelelahan mata pada juru las PT. X di Kabupaten Gresik.

\section{PEMBAHASAN}

\section{Hubungan antara Umur dengan Kelelahan Mata}

Berdasarkan hasil penelitian menunjukkan bahwa dari responden yang berjumlah 20 orang, kelompok umur juru las yang berada di PT. X sebagian besar berumur 26-35 tahun. Melalui uji Spearman diperoleh nilai $p=0,007 \alpha=0,05(p<\alpha)$ sehingga Ho ditolak. Jadi, terdapat hubungan antara umur dengan kelelahan mata pada juru las PT. X di Kabupaten Gresik.

Juru las membutuhkan kondisi fisik serta keterampilan yang baik agar dapat menghasilkan produktivitas yang tinggi. Kelompok umur 26-35 tahun merupakan puncak dari perkembangan fisik manusia sehingga produktivitas yang tinggi dapat tercapai terutama pada pekerjaan yang membutuhkan fisik baik seperti juru las. Oleh karena itu kelompok umur juru las yang mayoritas berusia 26-35 tahun merupakan kelompok umur yang optimal dari pekerjaan ini.
Kelompok umur 26-35 tahun merupakan kelompok umur yang paling banyak mengalami kelelahan mata karena jumlah juru las yang berada pada kelompok umur ini lebih banyak dibandingkan kelompok umur lainnya. Meskipun banyak kelelahan mata terjadi pada kelompok umur ini, kemungkinan juru las mengalami kelelahan mata akan meningkat apabila dilihat dari proporsi ada atau tidak adanya kelelahan mata berdasarkan kelompok umur. Kelompok umur di bawah 25 tahun yang mengalami kelelahan mata $67 \%, 82 \%$ pada kelompok umur 26-35 tahun, dan $100 \%$ pada kelompok umur diatas 36 tahun.

Fowler (2003), menyatakan bahwa pada usia 35 tahun keatas seseorang akan mengalami penurunan ketajaman penglihatan. Terjadinya penurunan ketajaman penglihatan menunjukkan bahwa terjadi penurunan fungsi organ tubuh khususnya pada organ penglihatan. Selama mengelas, kemampuan fungsi organ penglihatan yang baik sangat dibutuhkan karena juru las diharuskan menatap objek sambungan las yang berukuran kecil serta terpapar intensitas cahaya las yang tinggi.

Menurut Tarwaka dkk (2004), kemampuan fisik seseorang akan meningkat selama beberapa tahun dari awal hingga mencapai puncaknya pada umur 25-30 tahun. Umur 25-30 tahun merupakan kelompok umur dengan kemampuan fisik yang paling baik dalam siklus hidup manusia. Melalui pernyataan ini dapat disimpulkan bahwa terdapat hubungan antara umur dengan kemampuan fungsi organ tubuh.

Kemampuan fisik tubuh akan menurun secara bertahap sepanjang bertambahnya umur setelah kemampuan fisik tubuh mencapai puncaknya. Menurut Simanjuntak (2007), penurunan fungsi organ tubuh sebagai akibat dari perubahan fisiologis tubuh merupakan proses yang normal yang akan terjadi kepada setiap manusia yang telah mencapai usia dewasa. Pernyataan tersebut dapat dimaknai bahwa tenaga kerja dan pihak terkait perlu melakukan tindakan dalam menjaga kondisi dan mengoptimalkan kemampuan fisik juru las di perusahaan.

Terdapat hubungan antara umur dengan kelelahan mata terjadi karena adanya penurunan fungsi organ tubuh khususnya penurunan fungsi penglihatan yang sejalan dengan bertambahnya umur seseorang. Penelitian oleh Omokhua dan George (2010), juga menyatakan bahwa terdapat hubungan antara umur dengan kelelahan mata. Penelitian tersebut menyatakan bahwa dengan 
meningkatnya umur seseorang, maka terjadinya kelelahan mata pada seseorang menjadi meningkat secara signifikan.

Margrain dan Thompson (2002) dalam Omokhua dan George (2010), berpendapat bahwa umur adalah salah satu faktor yang dapat mempengaruhi hasil kelelahan mata yang menggunakan Photostress Recovery Test. Tes tersebut menyatakan bahwa terdapat hubungan antara umur dengan kelelahan mata terjadi karena adanya degradasi kemampuan mata akibat bertambahnya umur. Kemampuan mata dalam memutihkan pigmen cahaya sebagai adaptasi kadar cahaya lingkungan akan menurun sebagai akibat penurunan fungsi retina dan saraf.

Salah satu kemampuan fungsi organ yang menurun sejalan dengan umur adalah fungsi penglihatan. Penurunan fungsi penglihatan terjadi pada otot akomodasi dan retina mata. Penurunan fungsi otot akomodasi menyebabkan penurunan visus mata. Sedangkan penurunan fungsi retina menyebabkan memperpanjang waktu adaptasi kadar cahaya lingkungan.

Penurunan fungsi sel disebabkan penurunan kemampuan sel tubuh dalam menggantikan peran sel sebelumnya. Pada kasus penurunan fungsi organ akibat bertambahnya usia, kemampuan sel pada otot akomodasi dan retina mata juga mengalami degradasi. Dengan berkurangnya jumlah sel yang memiliki fungsi yang baik, maka fungsi jaringan tersebut juga akan mengalami penurunan kemampuan.

Fungsi otot akomodasi mata untuk memfokuskan objek serta retina untuk menerima rangsang cahaya membutuhkan fungsi jaringan yang optimal agar dapat menerima dan menerjemahkan gambaran objek dengan cepat di otak. Kondisi fungsi jaringan yang optimal hanya dapat terjadi apabila sel-sel pada jaringan tersebut memiliki kondisi yang baik. Kondisi sel-sel yang terbaik pada siklus hidup manusia adalah ketika masa dewasa muda. Pada masa usia tua, sel-sel tersebut akan mengalami degradasi fungsi sel.

Retina merupakan lapisan terdalam dari mata yang berfungsi seperti film dalam kamera. Di dalam retina terdapat sel fotosintesis yang disebut dengan sel kerucut dan sel batang. Rangsangan cahaya menyebabkan reaksi kimia dengan iodopsin pada sel kerucut saat kondisi terang atau rodopsin pada sel batang saat kondisi gelap (Hall, 2013).

Di dalam retina, terdapat fovea yang penting dalam mengoptimalkan kinerja mata ketika terpapar intensitas cahaya yang tinggi. Fovea mengurangi efek kabur ketika terjadi paparan tersebut. Fovea juga selalu berbanding lurus dengan ketajaman mata serta memberikan peningkatan kontras dari objek dengan latar belakang sehingga peran fovea penting untuk mengurangi dampak dari disability glare pada mata (Stringham dkk, 2013).

Retinal persistence adalah sel mata tidak bekerja dalam jangka waktu yang pendek ketika terjadi reaksi fotokimia dengan iodopsin maupun rodopsin. Hal ini merupakan penyebab pandangan mata menjadi kabur setelah terpapar cahaya yang menyilaukan. Variasi lamanya retinal persistence tergantung pada faktor individu, umur, penyakit, dan seberapa sering serta lama paparan dari cahaya yang menyilaukan. Paparan yang berulang-ulang dapat menyebabkan gangguan kesehatan seperti penurunan sensitivitas terhadap kedipan dan melumpuhkan proses pengiriman informasi visual. Pada kasus juru las, paparan yang berulang-ulang pada akhirnya dapat menyebabkan dampak yang irreversible pada mata. Kemampuan mata dalam menerima informasi visual menjadi lebih lama yang mirip seperti penuaan dini (Hall, 2013).

\section{Hubungan antara Intensitas Cahaya Las dengan Kelelahan Mata}

Berdasarkan hasil pengamatan yang didapat, diketahui bahwa nilai intensitas cahaya las yang di masing-masing tempat kerja juru las memiliki hasil yang berbeda-beda. Nilai yang paling rendah adalah 758 lux hingga nilai yang paling tinggi adalah 2025 lux. Berdasarkan nilai terendah dan tertinggi tersebut didapatkan range sebesar 1267 lux serta nilai ratarata intensitas cahaya las sebesar 1505 lux.

Berdasarkan uji normalitas didapatkan bahwa untuk data intensitas cahaya las $\mathrm{p}=0,31 \alpha=0,05$ $(\mathrm{p}>\alpha)$ dan kelelahan mata $\mathrm{p}=0,771 \alpha=0,05(\mathrm{p}$ $>\alpha$ ). Melalui uji normalitas tersebut maka dapat dinyatakan bahwa distribusi data intensitas cahaya las dan kelelahan mata normal. Melalui uji Pearson Product Moment diperoleh nilai $\mathrm{p}=0,023 \alpha=0,05$ $(\mathrm{p}<\alpha)$ sehingga Ho ditolak. Jadi terdapat hubungan antara intensitas cahaya las dengan kelelahan mata pada juru las PT. X di Kabupaten Gresik.

Terdapat hubungan antara intensitas cahaya las dengan kelelahan mata karena intensitas cahaya las yang tinggi akan menyebabkan mata mengalami adaptasi terang dan gelap lebih kuat dari kondisi normal. Menurut Marsida (1999), rangsangan cahaya yang masuk ke dalam organ penglihatan akan mempengaruhi reaksi fotokimia yang berada di retina. Apabila terjadi paparan cahaya yang 
tinggi, maka retina akan membatasi jumlah cahaya yang masuk dengan melakukan adaptasi gelap dan terang.

Menurut Suharyanto dan Safari (2010), semakin kuat intensitas cahaya yang terpapar selama bekerja khususnya pada pekerjaan yang dituntut untuk memandang objek pekerjaan, maka proses fotokimia yang terjadi di retina akan semakin memanjang. Proses fotokimia di retina yang semakin lama membutuhkan waktu pemulihan makula di retina yang semakin lama juga. Apabila dibandingkan dengan paparan intensitas cahaya yang lebih rendah maka akan menghasilkan pemulihan makula yang lebih rendah dibandingkan paparan intensitas cahaya yang tinggi.

Bunga api las yang muncul secara cepat menghasilkan intensitas cahaya yang tinggi sehingga mata melakukan adaptasi terang dengan cepat dan kuat. Ketika mesin las dijauhkan dari bahan las, maka bunga api las yang awalnya muncul menjadi menghilang sehingga intensitas cahaya berkurang dengan cepat kembali pada intensitas cahaya lingkungan awal. Pada proses ini terjadi adaptasi gelap dengan kuat karena penurunan intensitas cahaya sangat signifikan pada penglihatan manusia.

Terjadinya adaptasi terang dan gelap pada mata mengakibatkan terjadinya proses fotokimia di dalam retina. Pada pengelasan, adaptasi terang dan gelap oleh mata juru las terjadi sangat kuat karena perubahan intensitas cahaya di medan pandang juru las sangat cepat. Kondisi ini akan terjadi pada juru las selama jam kerja berlangsung.

Menurut Mangunkusumo (2002) dalam Hanum (2008), kelelahan mata dapat dipengaruhi oleh faktor intrinsik dan faktor ekstrinsik. Salah satu faktor ekstrinsik yang mempengaruhi kelelahan mata adalah kuantitas dan kualitas iluminasi. Kuantitas intensitas cahaya yang tinggi serta berpusat dari satu titik saja mengakibatkan terjadinya kontras cahaya dengan lingkungan. Kontras cahaya yang ditatap oleh juru las akan menyebabkan kelelahan mata.

Menurut Amstrong (1992) dalam Tarwaka dkk (2004) menyatakan bahwa tingkat pencahayaan yang berlebih dapat menyebabkan glare, reflection, excesive shadows, visibilitas, dan eyestrain. Dampak paparan intensitas cahaya yang tinggi akan mempengaruhi kemampuan adaptasi terang dan gelap pada mata. Adaptasi terang dan gelap terjadi dengan cepat dan berulang-ulang serta paparan cahaya yang tinggi secara tiba-tiba dapat menyebabkan kesilauan dan kelelahan mata.

Kepekaan terhadap kontras yang dirasakan oleh mata akan terasa sangat kuat oleh juru las karena dengan adanya bunga api las maka akan terjadi selisih intensitas cahaya yang tajam. Kepekaan terhadap kontras akan dirasakan lebih tajam akibat perubahan intensitas cahaya dari pengelasan naik secara cepat dalam waktu yang singkat. Meskipun mata memiliki kemampuan adaptasi gelap-terang maupun sebaliknya, penggunaan kemampuan mata secara intensif dari pengelasan akan menurunkan ketahanan mata dalam melakukan fungsinya.

Intensitas cahaya las memiliki nilai yang sangat tinggi karena cahaya yang muncul berasal dari percikan bunga api las yang banyak di pusat titik las. Bunga api las yang padat di pusat titik las memicu terjadinya kontras cahaya yang tinggi terhadap lingkungan sekitar. Kontras cahaya terjadi karena terdapat perbedaan intensitas cahaya di satu titik dengan lingkungan sekitarnya.

Nilai intensitas cahaya yang dihasilkan dari pengelasan dapat berbeda-beda tergantung pada jenis mesin las, jenis pekerjaan pengelasan, serta jenis dan bahan logam yang dilas. Variasi dari faktor-faktor tersebut akan memengaruhi tingkat panas yang dihasilkan dan akan menghasilkan nilai intensitas cahaya yang beragam. Nilai intensitas cahaya las yang beragam memiliki kaitan terhadap kejadian kelelahan mata pada juru las.

Sifat cahaya yang muncul dari proses pengelasan termasuk dalam pencahayaan yang buruk. Menurut Santoso (2004), salah satu faktor yang dapat menentukan kondisi tempat kerja memiliki pencahayaan yang baik atau tidak adalah kontras antara objek dengan lingkungan sekitarnya. Panas yang dihasilkan dari pengelasan akan menghasilkan intensitas cahaya yang tinggi di suatu titik sehingga menyebabkan kontras cahaya yang tinggi antara objek yang ditatap oleh juru las dengan lingkungan sekitarnya.

Cahaya yang dihasilkan dari proses pengelasan memiliki sifat pembagian luminansi yang kurang baik. Pembagian luminansi yang kurang baik dalam medan pandang dapat menyebabkan kesilauan dan cahaya panas sehingga menyebabkan kelelahan mata. Menurut Suma'mur (2009), cahaya las memiliki efek cahaya yang buruk tidak hanya pada juru las namun juga kepada orang-orang yang berada di sekitar pengelasan. Efek cahaya yang buruk dari pengelasan tidak dapat dihilangkan sehingga pengendalian yang terbaik adalah dengan memakai alat pelindung diri berupa face shield pada juru las dan goggle pada orang di sekitar proses pengelasan.

Menurut Angelina dan Oginawati (2010), intensitas cahaya yang tinggi akan menimbulkan kesilauan dan dapat mengganggu penglihatan dan 
Tabel 3. Nilai Ambang Batas Radiasi UV Yang Diperkenankan

\begin{tabular}{lccc}
\hline Masa Pemajanan Per Hari & Iradiasi Efektif $\mu \mathbf{W} / \mathbf{c m}^{\mathbf{2}}$ & Masa Pemajanan Per Hari & Iradiasi Efektif $\mu \mathbf{W} / \mathbf{c m}^{\mathbf{2}}$ \\
\hline 8 jam & 0,1 & 5 menit & 10 \\
4 jam & 0,2 & 1 menit & 50 \\
2 jam & 0,4 & 30 detik & 100 \\
1 jam & 0,8 & 10 detik & 300 \\
30 menit & 1,7 & 1 detik & 3000 \\
15 menit & 3,3 & 0,5 detik & 6000 \\
10 menit & 5 & 0,1 detik & 30000 \\
\hline
\end{tabular}

Sumber: Keputusan Menteri Tenaga Kerja Nomor 51 Tahun 1999 Tentang Nilai Ambang Batas Faktor Fisika di Tempat Kerja

menyebabkan rasa letih pada mata. Terjadinya kesilauan dipengaruhi oleh tingginya luminasi, besar sumber cahaya, posisi pengamat terhadap sumber cahaya dan kontras antara tengah medan pandang dengan lingkungan sekitar. Terjadinya kelelahan mata pada juru las dapat menyebabkan penurunan semangat kerja sehingga berdampak pada produktivitasnya.

Juru las yang menatap sumber cahaya secara langsung akan mengalami kesilauan jenis disability glare. Juru las akan mengalami disability glare karena sumber cahaya yang memiliki intensitas cahaya yang tinggi berada di pusat medan pandang. Terjadinya disability glare pada juru las akan memicu terjadinya flash blindness pada juru las.

Kondisi lain terjadi pada orang di sekitar pengelasan selain juru las. Orang yang berada di sekitar pengelasan tersebut tidak akan mengalami disability glare, tetapi akan mengalami discomfort glare. Discomfort glare akan menyebabkan orang yang berada di sekitar pengelasan mengalami visual discomfort. Kondisi ini akan memberikan rasa ketidaknyamanan pada orang di sekitar pengelasan terlebih lagi jika kondisi tersebut terjadi dalam jangka waktu yang lama.

Tidak hanya paparan intensitas cahaya dari sinar tampak, namun proses pengelasan juga menimbulkan paparan radiasi sinar ultraviolet terhadap orangorang yang berada di dekat pengelasan. Menurut Angelina dan Oginawati (2010), radiasi sinar ultraviolet dapat terserap oleh jaringan kulit, kornea, dan epitel konjungtiva. Paparan radiasi ultraviolet pada kornea dalam jangka waktu yang panjang dapat menyebabkan terjadinya fotokeratitis. Nilai ambang batas paparan radiasi sinar ultraviolet telah ditetapkan oleh pemerintah melalui Keputusan Menteri Tenaga Kerja Nomor 51 tahun 1999 tentang Nilai Ambang Batas Faktor Fisika di Tempat Kerja pada Tabel 3.
Apabila merujuk pada NAB yang telah ditetapkan oleh Kepmenaker No. 51 Tahun 1999 tentang Nilai Ambang Batas Faktor Fisika Di Tempat Kerja, maka paparan sinar las tidak boleh lebih dari $0,1 \mu \mathrm{W} / \mathrm{cm}^{2}$ dalam 8 jam kerja per hari. Berdasarkan penelitian yang dilakukan oleh Angelina dan Oginawati (2010), diketahui bahwa nilai rata-rata intensitas UV dari pengelasan yang terpapar pada mata yang menggunakan faceshield mencapai 13 $\mu \mathrm{W} / \mathrm{cm}^{2}$. Nilai intensitas UV sangat bervariasi dari 0,3 hingga $30 \mu \mathrm{W} / \mathrm{cm}^{2}$. Nilai intensitas UV dapat dikurangi secara signifikan dengan pengaturan posisi juru las yang membelakangi cahaya matahari atau tertutup oleh atap.

Kaca faceshield dapat berasal dari bahan polikarbonat, propionat, asetat, polietilen terephthalat glikol (PETG), baja, maupun nilon sesuai dengan karakteristik pekerjaannya. Kaca faceshield yang paling baik untuk digunakan dalam proses pengelasan adalah yang berasal dari bahan polikarbonat. Kaca faceshield yang berbahan dasar polikarbonat sangat tepat karena bahan ini tahan panas dan memberikan perlindungan dari percikan paparan kimia dengan baik (Grainger, 2015).

Penggunaan kaca faceshield yang tepat tidak hanya pada pemilihan bahannya, tetapi juga pada penentuan nomor filter yang sesuai dengan jenis pengelasan yang sedang dilakukan. Penentuan nomor filter tergantung pada jarak terhadap pengelasan, jenis mesin las, jenis dan bahan yang dilas, serta kuat arus mesin las. Berdasarkan Tabel 4, diketahui bahwa nomor filter bervariasi dari yang paling terang yaitu filter nomor 2 hingga yang paling gelap filter nomor 14 (Siswanto, 1994).

Menurut Hammond dkk (2013), penggunaan filter dapat mengurangi kesilauan dengan menyerap cahaya gelombang pendek. Kegagalan atau kurang tepatnya penggunaan filter dapat menyebabkan 
Tabel 4. Penentuan Nomor filter yang Dianjurkan

\begin{tabular}{|c|c|}
\hline Jenis Pekerjaan & Nomor Filter yang Dianjurkan \\
\hline $\begin{array}{l}\text { 1. Pengelasan jarak jauh dan proses pemotongan logam. } \\
\text { 2. Bekerja di dekat daerah pengelasan. }\end{array}$ & $\begin{array}{l}\text { Lensa yang terang atau filter (shade lens) } \\
\text { sampai no. } 2 \text { (clear to \# 2). }\end{array}$ \\
\hline $\begin{array}{l}\text { 1. Las Karbid (oxy-fuel welding) dengan ujung yang berukuran kecil } \\
\text { (small tips). } \\
\text { 2. Memotong logam yang tipis. }\end{array}$ & Filter sampai no. 5 (shade to \# 5). \\
\hline $\begin{array}{l}\text { 1. Las busur listrik (metal-arc welding). } \\
\text { 2. Las karbid (oxy-fuel welding). } \\
\text { 3. Pemotongan logam yang cukup tebal (intermediate thickness). }\end{array}$ & Filter sampai no. 6 (shade to \# 6). \\
\hline $\begin{array}{l}\text { 1. Las busur listrik sampai } 75 \text { Ampere (metal-arc welding). } \\
\text { 2. Las karbid (oxy-fuel welding). } \\
\text { 3. Pemotongan logam yang tebal. }\end{array}$ & Filter sampai no. 8 (shade to \# 8). \\
\hline $\begin{array}{l}\text { 1. Las Busur listrik dan pemotongan logam } 75-200 \text { Ampere. } \\
\text { 2. Las dengan pelindung gas lembam (gas shielded welding and } \\
\text { cutting) sampai } 50 \text { Ampere. }\end{array}$ & Filter sampai no. 10 (shade to \# 10). \\
\hline $\begin{array}{l}\text { 1. Metal-arc welding and cutting 200-400 Ampere. } \\
\text { 2. Gas shielded welding and cutting 150-200 Ampere. }\end{array}$ & Filter sampai no. 12 (shade to \# 12). \\
\hline $\begin{array}{l}\text { 1. Metal-arc welding and cutting lebih besar dari } 400 \text { Ampere. } \\
\text { 2. Gas shielded welding and cutting lebih besar dari } 200 \text { Ampere. }\end{array}$ & Filter sampai no. $14+$ tinted flash goggles. \\
\hline
\end{tabular}

Sumber: Siswanto, 1994

gangguan pada mata akibat meningkatkan paparan cahaya yang melalui kornea dan lensa mata. Penggunaan nomor filter yang tepat sesuai kriteria pekerjaan dapat mengurangi paparan intensitas cahaya yang masuk ke organ penglihatan.

Paparan yang tinggi dari intensitas cahaya dapat menyebabkan kerusakan pada retina yang tidak dapat diperbaiki. Paparan singkat dari cahaya dapat menyebabkan thermal injury. Paparan cahaya dalam jangka waktu yang panjang memungkinkan terjadinya perubahan kimia dalam sel retina sehingga menyebabkan kematian sel. Hal tersebut dikenal sebagai kerusakan fotokimia. Kerentanan terhadap kerusakan fotokimia dapat disebabkan oleh multifaktor seperti usia, pola makan dan penyakit. Berdasarkan penelitian pada anjing, terdapat peningkatan sensitivitas dari efek negatif paparan cahaya. Peningkatan sensitivitas terhadap cahaya akan terjadi juga pada juru las selama terpapar oleh intensitas cahaya las (Hunter dkk, 2012).

Terdapat dua jenis kerusakan fotokimia, yaitu paparan singkat dan paparan yang lama. Paparan singkat yaitu paparan yang hanya sampai 12 jam akan menyebabkan kerusakan fotokimia pada sel RPE dan sel lainnya yang berkaitan. Paparan yang lama adalah paparan yang terjadi 12 hingga 48 jam akan berdampak pada bagian di luar fotoreseptor (Heilig dkk, 2009).

Sel batang dan kerucut yang berada di retina diduga akan mengalami kerusakan yang paling pertama ketika terjadi paparan intensitas cahaya yang tinggi. Hal yang sama terjadi pada sel RPE atau Retinal Pigment Epithelium yang berfungsi menyerap cahaya akan retan terhadap kerusakan fotokimia. Kerusakan fotokimia yang terjadi pada sel batang, kerucut, maupun RPE dapat menyebabkan kerusakan yang lebih parah terhadap penyakit yang ada di retina. Kerusakan fotokimia dapat terjadi ketika paparan cahaya mampu merusak sel di dalam mata melalui radiasi. Paparan cahaya mampu merusak sel karena dapat memecah molekul yang ada pada sel. Pada paparan yang tinggi dan berulangulang, sel yang rusak dapat mengalami kematian sel (Hunter dkk, 2012).

\section{SIMPULAN}

Berdasarkan hasil pengukuran intensitas cahaya las di PT. X, nilai rata-rata intensitas cahaya las adalah 1505 lux dengan nilai terendah adalah 758 lux dan nilai tertinggi adalah 2025 lux. Hasil pemeriksaan kelelahan mata, menunjukkan bahwa sebagian besar juru las PT. X di Kabupaten Gresik mengalami kelelahan mata sebanyak 17 orang (85\%). Mayoritas juru las memiliki umur 26-35 tahun sebanyak 11 orang (55\%).

Hubungan antar variabel menunjukkan bahwa terdapat hubungan antara umur dengan kelelahan mata pada juru las PT. X di Kabupaten Gresik, serta terdapat hubungan antara intensitas 
cahaya las dengan kelelahan mata pada juru las PT. X di Kabupaten Gresik. Pengendalian yang dapat dilakukan untuk mencegah kelelahan mata adalah Juru las harus menggunakan alat pelindung diri berupa faceshield yang sesuai dengan jenis pengelasannya. Perusahaan juga harus mengadakan pemeriksaan mata rutin dan konseling terhadap juru las secara rutin.

\section{DAFTAR PUSTAKA}

Andryansyah. 2000. Kesehatan dan Keselamatan Kerja Pengelasan Dalam Ruang Terbatas. Buletin Keselamatan Statuta, Vol. 1, 52-55.

Angelina, C. dan K. Oginawati. Paparan Fisis Pencahayaan terhadap Mata dalam Kegiatan Pengelasan (Studi Kasus: Pengelasan di Jalan Bogor). http://www.ftsl.itb.ac.id/kk/ teknologi_pengelolaan_lingkungan/wp-content/ uploads/2010/10/PI-EH6-Cory-Angelina15305015.pdf (Sitasi 26 Desember 2014)

Fitriadi, R. 2008. Penentuan Prioritas Alternatif Pengelasan Pada Body Welding Minibus. Simposium Nasional RAPI VII 2008, I-66 I-73.

Fowler, B. 2003. Functional and Biological Markers of Aging. Dalam: Klatz, R. 2003. Anti-Aging Medical Therapeutics, Vol. 5. Chicago: The A4M Publications.

Grainger. Faceshield Protection. https://www. grainger.com/content/qt-face-shield-protection373 (Sitasi 24 Januari 2016)

Grandjean, E. 1988. Fitting The Task to The Man: A Textbook of Occupational Ergonomics $4^{\text {th }}$ Edition. London: Taylor \& Francis.

Hall, S. Safety and Ergonomics in Welding: Need For A New Generation Of Welding Helmet Suited To Pulsed Welding Arcs. http:// supporting-paa.wikispaces.com/file/detail/ Pulsed+welding+eye+strain.pdf(Sitasi 12 Januari 2016)

Hammond Jr., B.R., Fletcher L.M.,dan J.G. Elliott. 2013. Glare Disability, Photostress Recovery, and Chromatic Contrast: Relation to Macular Pigment and Serum Lutein and Zeaxanthin. Investigative Ophthalmology \& Visual Science, Vol. 54, No. 1.

Hanum, I.F. 2008. Efektivitas Penggunaan Screen pada Monitor Komputer untuk Mengurangi Kelelahan Mata Pekerja Call Centre di PT. Indosat
Heilig, P., E. Rozanova, J. Godnic-Cvar. Retinal Light Damage. http://www.lightmare.org/docs/ Retinal_Light_Damage_RLD2529_en.pdf(Sitasi 12 Januari 2016)

Hunter, J.J., J.I.W. Morgan, W.H. Merigan, D.H. Sliney, J.R. Sparrow, dan D.R. Williams. 2012. The Susceptibility of The Retina To Photochemical Damage from Visible Light. Progress in Retinal and Eye Research $3128 e 42$.

Ito, Y., M. Horiguchi, Y., Miyake., S. Awaya. 1997. Extrafoveal Photostress Recovery Testing With a Scanning Laser Ophthalmoscope. Jpn J Ophthalmol 1997; 41: 255-259.

Kementerian Tenaga Kerja. 1999. Keputusan Menteri Tenaga Kerja Nomor 51 tahun 1999 Tentang Nilai Ambang Batas Faktor Fisika di Tempat Kerja. Jakarta: Kementerian tenaga Kerja.

Marsida, A.Y. 1999. Photostress Recovery Test pada Penderita Hipertensi. Tesis. Medan, Universitas Sumatera Utara.

Omokhua, P.O., O.G. George. 2010. Photostress Recovery Time Among Nigerians. JNOA, Vol. 16, 16-20.

Santoso, G. 2004. Manajemen Keselamatan dan Kesehatan Kerja. Jakarta: Prestasi Pustaka.

Sedarmayanti. 2011. Tata Kerja dan Produktivitas Kerja. Bandung: CV Mandar Maju.

Setiawan, D. 2015. Faktor yang Berhubungan dengan Kelelahan Mata pada Juru Las di PT. X. Skripsi. Surabaya, Universitas Airlangga.

Simanjuntak, L.F. 2007. Pengaruh dan Hubungan Umur Terhadap Kapasitas Vital pada Pria Dewasa Normal. Skripsi. Bandung, Universitas Kristen Maranatha.

Siswanto, A. 1994. Bahaya Las. Balai Hiperkes dan Keselamatan Kerja Jawa Timur Departemen Tenaga Kerja.

Stringham, J.M., P.V. Garcia, P.A. Smith, L.N. McLin, dan B.K. Foutch. 2011. Macular Pigment and Visual Performance in Glare: Benefits for Photostress Recovery, Disability Glare, and Visual Discomfort. Investigative Ophthalmology \& Visual Science, Vol. 52, No. 10.

Suharyanto, F.X., E. Safari. 2010. Asthenopia Pada Pekerja Wanita Di Call Centre-X. Buletin Penelitian Kesehatan Vol. 38, No. 3, 119-130.

Suma'mur. 2009. Higiene Perusahaan dan Kesehatan Kerja (Hiperkes). Jakarta: CV Sagung Seto.

Tarwaka, B., L. Sudiajeng. 2004. Ergonomi Untuk Keselamatan, Kesehatan Kerja dan Produktivitas. Surakarta: UNIBA Press. 